\title{
A histomorphometric study of unmyelinated fibers of the fibular nerve in Wistar rats
}

\author{
Histomorfometria das fibras amielínicas do nervo fibular em ratos Wistar \\ Vânia Tognon-Miguel', Adriana Helena do Nascimento-Elias ${ }^{1,2}$, Maria Cristina Lopes Schiavoni', Amilton \\ Antunes Barreira ${ }^{1}$
}

\begin{abstract}
There are few histomorphometric studies on the unmyelinated fibers of the fibular nerve in rats, and the number of experimental studies using this nerve has been increasing in the last years. Sixty-two percent of the endoneurial area from 10 fibular nerves of adult Wistar rats was scanned by electron microscopy, and digitized. The total number of unmyelinated axons (1.882 \pm 271$)$ was significantly lesser, and their axon diameters $(0.2 \mu \mathrm{m}$ to $2.8 \mu \mathrm{m})$ significantly higher than that determined in previous studies. The histogram peaked at $1 \mu \mathrm{m}$. The differences could be due to the nerve sampled area, the number and the age of the animals evaluated, and the laboratory techniques used. This study brings new and referential data to be used in experimental investigations involving histomorphometric evaluation of the rat fibular nerve.
\end{abstract}

Keywords: unmyelinated fibers, unmyelinated; peroneal nerve; microscopy, electron, transmission; peripheral nerves.

\section{RESUMO}

Embora o nervo fibular de ratos venha sendo incluído progressivamente em maior número de estudos experimentais nos últimos anos, há poucos estudos a respeito das suas fibras amielínicas. Os nervos fibulares de 10 ratos Wistar adultos foram avaliados através de microscopia óptica e eletrônica. Varredura sistemática através de microscopia eletrônica de transmissão das áreas fasciculares da porção distal no nervo foi realizada. Em média, $62 \%$ da área endoneural foi digitalizada. 0 número total de axônios amielínicos encontrados $(1.882 \pm 271)$ foi significativamente menor e as medidas dos diâmetros axonais $(0,2 \mu \mathrm{m}$ a 2,8 $\mu \mathrm{m})$ maiores do que o determinado em estudos prévios. 0 pico do histograma foi constituído por fibras de $1 \mu \mathrm{m}$. As diferenças podem ser devidas à amostragem de maior área endoneural, ao número e à idade dos animais avaliados, e as técnicas laboratoriais utilizadas. Os dados obtidos podem ser considerados referenciais para o nervo fibular de ratos Wistar adultos.

Palavras-chave: fibras nervosas amielínicas; nervo fibular; microscopia eletrônica de transmissão; nervos periféricos.

In recent years, interest in the morphometry of the fibular nerve has increased due to various experimental studies, including its use as a model for nerve regeneration. The use of the fibular nerve in studies of nerve regeneration was boosted after the reintroduction of the end-to-side neurorrhaphy ${ }^{1,2,3,4,5,6,7,7,8,9,10,11,23,13}$. We were not able to find many references to the unmyelinated axons of the fibular nerve in these and other recent studies. Few investigations have been devoted to gathering histomorphometric data about these axons. One research paper showed that unmyelinated fibers in the fibular nerve include both sympathetic (27\%), and sensory fibers (73\%), and that the total number of unmyelinated axons ranged from 3,351 to $4,792^{14}$. Subsequent investigators reported values ranging from a minimum of 2,960 unmyelinated axons ${ }^{15}$ to a maximum of $5,000^{16}$. Few experiments using end-to-side neurorrhaphy with the previously sectioned fibular nerve addressed the issue of regeneration of unmyelinated fibers ${ }^{17-19}$. This study aims to evaluate aspects of the histology and morphology of the unmyelinated fibers of the rat common fibular nerve, bringing new and significant baseline anatomical data to researchers in the field of nerve regeneration and others.

\footnotetext{
1 Universidade de São Paulo, Faculdade de Medicina de Ribeirão Preto, Departamento de Neurociências e Ciências do Comportamento, Ribeirão Preto SP, Brasil; ${ }^{2}$ Universidade de São Paulo, Faculdade de Medicina de Ribeirão Preto, Departamento de Biomecânica, Medicina e Reabilitação do Aparelho Locomotor, Ribeirão Preto SP, Brasil.

Correspondence: Amilton Antunes Barreira; Faculdade de Medicina de Ribeirão Preto; Av. Bandeirantes 3900; 14049-900. Ribeirão Preto SP, Brasil. E-mail: aabarrei@fmrp.usp.br

Conflict of interest: There is no conflict of interest to declare.

Support: FAPESP (Processo: 2012/11012-7), CNPq (Processo: 141524/2015-4) and FAEPA (Fundação de Apoio ao Ensino, Pesquisa e à Assistência do Hospital das Clínicas da Universidade de São Paulo).

Received 08 December 2015; Accepted 16 March 2016.
} 


\section{METHOD}

\section{Animals}

The institutional "Animal Experimentation Ethics Committee" at the Medical School of Ribeirão Preto approved the study (024/2010). We performed analyzes of the fibular nerve using 10 adult female Wistar rats aged 130 days, and each weighing $250 \mathrm{~g}-300 \mathrm{~g}$. They were maintained with 12-hour light-dark cycle, a temperature of between $20-24^{\circ} \mathrm{C}$, and free access to food and water.

\section{Surgical procedures}

The animals were anesthetized using ketamine chloridrate $(75 \mathrm{mg} / \mathrm{kg})$ and xylazine $(15 \mathrm{mg} / \mathrm{kg})$ administered intraperitoneally. After the sciatic nerve and its branches were exposed (Figure 1), the fibular nerve was dissected. The nerves were moistened in situ using $2 \%$ glutaraldehyde and removed. The distal portion of the left common fibular nerve was immersed in a $2 \%$ glutaraldehyde solution for $48 \mathrm{~h}$ at $4^{\circ} \mathrm{C}$. The nerve fragment was washed with sodium cacodylate buffer, postfixed in $1 \%$ osmium tetroxide, and progressively

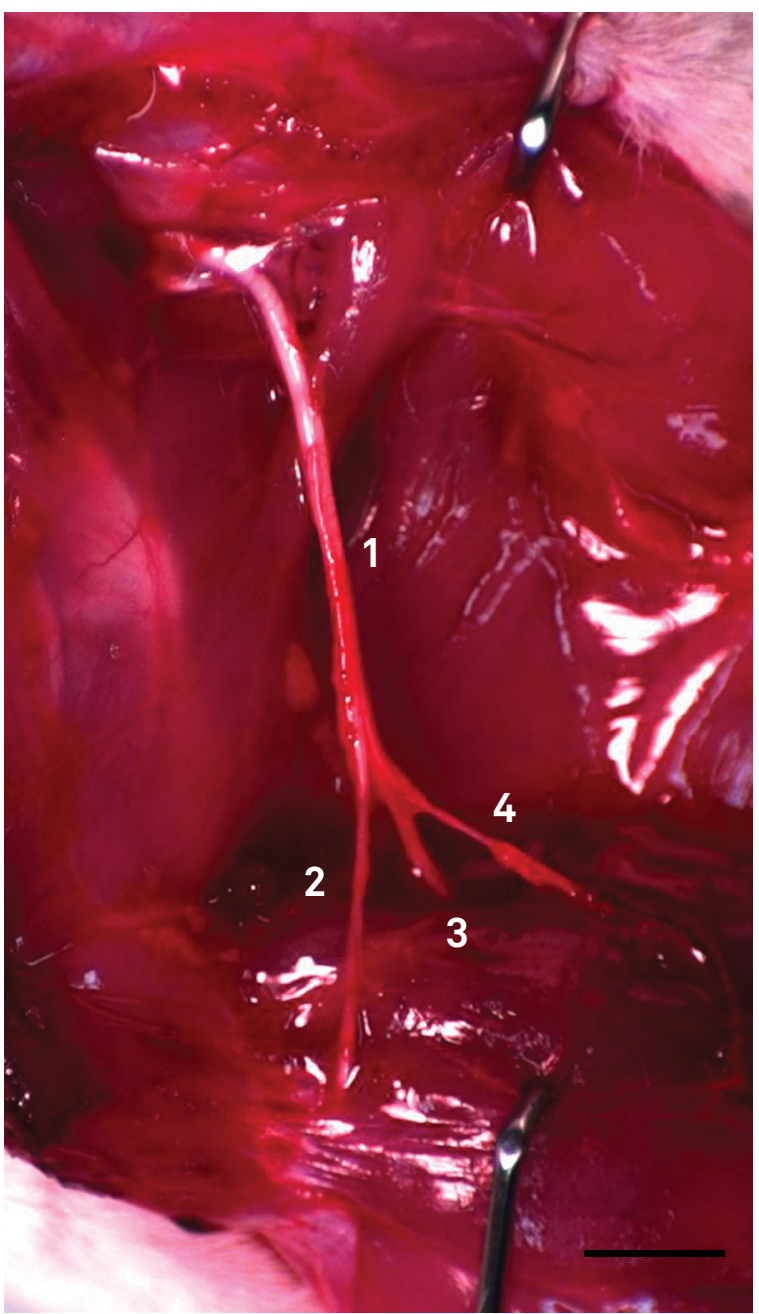

Figure 1. Wistar rat sciatic nerve and its branches. 1, sciatic nerve; 2 , common fibular nerve; 3 , tibial nerve; 4, sural nerve. Bar $=8 \mathrm{~mm}$. dehydrated and embedded in Epoxy resin (Epon 812). After removal of the nerve, the animals were euthanized using a double dose of the same anesthetics. The nerve was cut into $0.5 \mu \mathrm{m}$ thick sections using a microtome (MT 6000XL-RMC), stained with toluidine blue, and mounted using Entellan for light microscopy analysis. Details of the methods used have been published in previous studies ${ }^{6,20,21}$.

\section{Transmission electron microscopy procedures}

The plastic embedded blocks were cut using an ultramicrotome (Carl Zeiss, model G/214711) into 80 nm-thick sections. The sections were put on oval grids covered with 5\% Formvar film (Formvar Solution in Ethylene Dichloride, E.M.S. Inc) and stained with 5\% uranyl acetate and $0.5 \%$ lead citrate. They were analyzed using a transmission electron microscope (JEM-100CXII, JEOL Ltda.) equipped with a digital camera (Hamamatsu ORCA-HR, model C4742-51-12HR). The images were obtained sequentially to scan the complete cross-sectional area of each nerve fascicle. Even so, it was necessary to leave some gaps between two sequential samples to avoid overlapping of the scanned fields. Photomicrographs at 14,000X magnifications were taken manually and sequentially while scanning (Figure 2). We scanned $62 \%$ of each fascicle area. Each digital image obtained from microscopic fields was $14.0 \mu \mathrm{m}$ wide by $14.0 \mu \mathrm{m}$ high and $1024 \times 1024$ pixels in tagged image file format (TIFF), and all of them were analyzed. Due to the variability of the fascicular area, the average number of images obtained was around 413 per nerve.

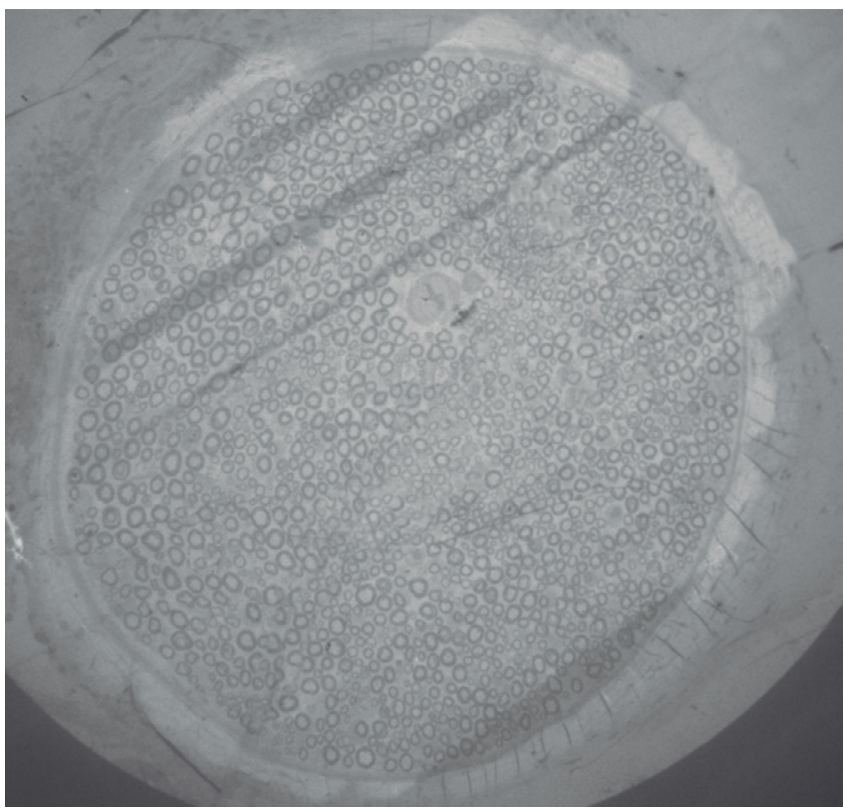

Figure 2. Fascicular area of common fibular nerve in the rat. A nerve fascicle after image capture for morphometry of the unmyelinated fibers. The electron beam marks the clear strips in the scanned area. The separation between the strips is not always evident due to the limited magnification used. Transmission electron microscopy - 200X. 


\section{Unmyelinated axons assessment}

The axonal area, total number of axons, axonal density (axons $/ \mathrm{mm}^{2}$ ), and the minimum axonal diameter $(\mu \mathrm{m})$ were measured using ImageJ software (ImageJ 1.47 National Institutes of Health (USA). The system was calibrated to obtain measurements of the axonal area and minimum diameter of unmyelinated axons. At 14,000X, every 1024 pixels corresponded to $14 \mu \mathrm{m}$.This value was obtained using an electron microscopic image of a $1 \mu \mathrm{m}$ mesh grid as reference. Each unmyelinated axon was surrounded using ImageJ's "polygon tool” (Figure 3). The selected and surrounded axons measurements were stored using the "ROI Manager" tool. Unmyelinated axons were correctly identified using established criteria ${ }^{22}: 1$. The axons had a circular or oval profile; 2 . They were surrounded by Schwann cell cytoplasm forming mesaxons; 3 . The axoplasm of unmyelinated axons was clearer than the cytoplasm of the respective Schwann cell; 4. the axons were clustered into "units", which had a direct relationship with Schwann cells; and 5. There was a basal lamina surrounding each fiber unit externally (Schwann cells and axons). Only axons with a circular shape were measured, and the irregular and obliquely sectioned axons were only counted. The area of each fascicle was analyzed. The internal fascicular area measures $\left(\mathrm{mm}^{2}\right)$ were similar to those obtained in semithin sections, and so we measured fascicular area in semithin sections (Figure 4). The methods that we used in this study are as reliable or more reliable than those used in our previous studies ${ }^{23-26}$. We represented the frequency distribution of the unmyelinated axons as a histogram, with axon diameters separated into class intervals increasing by $0.2 \mu \mathrm{m}$. All morphometric data were expressed as mean \pm standard deviation.

\section{Statistical analysis}

The obtained data were analyzed using SPSS v.17.0 (SPSS Inc., Chicago, IL, USA) statistical software. Student's t-test allowed the comparison of the total number of unmyelinated
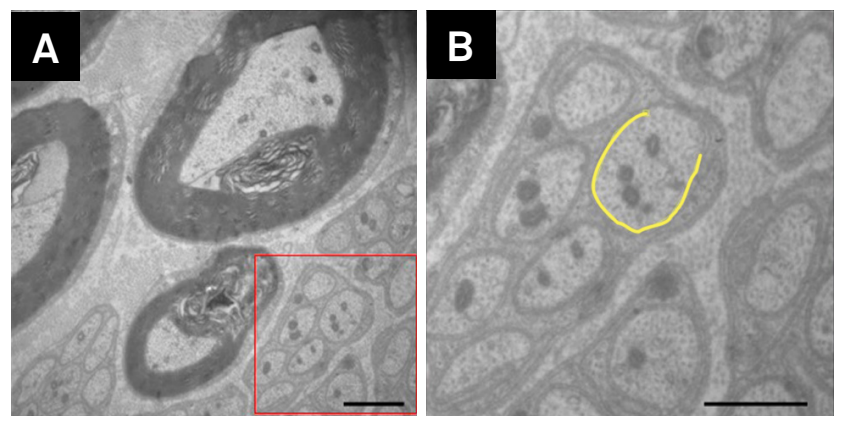

Figure 3. Example of the ImageJ tool use for measurement and counting of unmyelinated axons. An image with several unmyelinated fibers and myelinated fibers is showed at left. The red area highlights the enlarged portion of the frame at right. After manually outlining the axolemma (yellow line) the area and the axonal diameter are automatically measured. axons with other reports in the literature. Differences were considered significant when $\mathrm{p} \leq 0.05$.

\section{RESULTS}

The morphometric data obtained from the ten fibular nerves is presented in Tables 1 and 2. The frequency distribution obtained for axon diameter is presented as a histogram (Figure 4). Typical fibular nerve samples exhibited a single fascicle surrounded by a well-defined perineurium (Figure 5). The perineurium consisted of a uniform cell layer that separates the epineurium from the endoneurium.

Table 1. Histomorphometric parameters of the Wistar rat common fibular nerve and unmyelinated axons ( $n=10)$.

\begin{tabular}{lc}
\hline Nerve and unmyelinated components & Morphometric data \\
\hline Cross-sectional data & \\
Area $\left(\mathrm{mm}^{2}\right)$ & $0.13 \pm 0.02$ \\
Diameter $(\mathrm{mm})$ & $0.42 \pm 0.03$ \\
Unmyelinated Axons & \\
Total number & $1882 \pm 270.9$ \\
Density (axons $\left./ \mathrm{mm}^{2}\right)$ & $13935.0 \pm 1875.8$ \\
Minimum diameter $(\mu \mathrm{m})$ & 0.162 \\
Maximum diameter & 2.651 \\
\hline Medium diameter & $0.968 \pm 0.10$
\end{tabular}

Data are presented as the mean value \pm standard deviation (except for minimum diameter and maximum diameter)

Table 2. Number of unmyelinated axons and their respective percentage regarding to the diameters.

\begin{tabular}{|lccc}
\hline Diameter $(\mu \mathrm{m})$ & $\begin{array}{c}\text { Axon } \\
\text { number }\end{array}$ & $\%$ & $\begin{array}{c}\% \text { standard } \\
\text { deviation }\end{array}$ \\
\hline 0 & 0 & 0 & 0 \\
\hline $0-0.2$ & 12 & 0.1344 & 0.181315 \\
\hline $0.2-0.4$ & 392 & 43.892 & 1.605 .157 \\
\hline $0.4-0.6$ & 820 & 91.815 & 3.060 .046 \\
\hline $0.6-0.8$ & 1568 & 175.568 & 7.483 .982 \\
\hline $0.8-1.0$ & 2260 & 253.051 & 6.934 .683 \\
\hline $1.0-1.2$ & 1945 & 217.781 & 5.008 .334 \\
\hline $1.2-1.4$ & 1057 & 118.352 & 4.258 .786 \\
\hline $1.4-1.6$ & 495 & 55.425 & 3.681 .682 \\
\hline $1.6-1.8$ & 229 & 25.641 & 2.229 .697 \\
\hline $1.8-2.0$ & 80 & 0.8958 & 0.950093 \\
\hline $2.0-2.2$ & 49 & 0.5487 & 0.634384 \\
\hline $2.2-2.4$ & 14 & 0.1568 & 0.131428 \\
\hline $2.4-2.6$ & 8 & 0.0896 & 0.127118 \\
\hline $2.6-2.8$ & 1 & 0.0112 & 0.035408 \\
\hline $2.8-3.0$ & 0 & 0 & 0 \\
\hline
\end{tabular}


Unmyelinated axons could be distinguished from myelinated axons in photomicrographs. Unmyelinated axons could be characterized by the distinctive features of their mesaxons, microtubules, neurofilaments and the mitochondria in the endoneurial space. Their diameters were highly variable as was the degree of circularity of their cross sections. We also identified the following structures in endoneurial space: Schwann cells nuclei and cytoplasm, myelinated fibers, endothelial cells of capillaries, mast cells, fibroblasts, and collagen fibers that had been crosswise or obliquely. Schwann cell nuclei were recognized by their closeness to myelinated and unmyelinated axons (Figure 6). We measured 8,931 unmyelinated axons in the ten animals, and only counted the axons that at least partially appeared in the images. All studied nerves had a unimodal distribution of unmyelinated axon diameters. The peak of the histogram was at 1.0-1.2 $\mu \mathrm{m}$ (Figure 4).

\section{DISCUSSION}

We used previous data obtained in our laboratory to estimate that the ratio of myelinated fibers to unmyelinated axons in the common fibular nerve of adult Wistar rats is approximately $1: 1^{20}$. Although the rat common fibular nerve is mainly motor, we expected to find more unmyelinated axons than we did. Our results showed less than half the number of unmyelinated axons in the typical common fibular nerve than in a previous study, which estimated $4,171 \pm 565$ axons $^{14}$. A further study by the same group investigated the regenerated fibular nerves of Wistar rats after a nerve crush. They estimated 2,960 unmyelinated axons in the distal portion of the nerve and gave no standard deviations ${ }^{15}$. More than 4,600 unmyelinated axons were found in a study aiming to evaluate the effect of laser beams on nerve fibers of the fibular nerve in rats ${ }^{16}$.

Differences in the sample size used for estimating the total number of fibers and other methodological differences may at least partly explain the difference between our results and those of other authors. Our samples were fixed in $2 \%$ glutaraldehyde and embedded in Epoxy resin (Epon 812). The other authors perfused the hind paws with $4.0 \%, 2.5 \%$, and $5 \%$ glutaraldehyde respectively. The first two authors embedded their samples in Epon $812^{\circ}$ as we $\operatorname{did}^{14,15}$. One other author used Epon-Araldite ${ }^{16}$. The previous studies used conventional mesh grids to obtain their electron micrographs while we used oval grids with a single opening covered with a Formvar film. Conventional

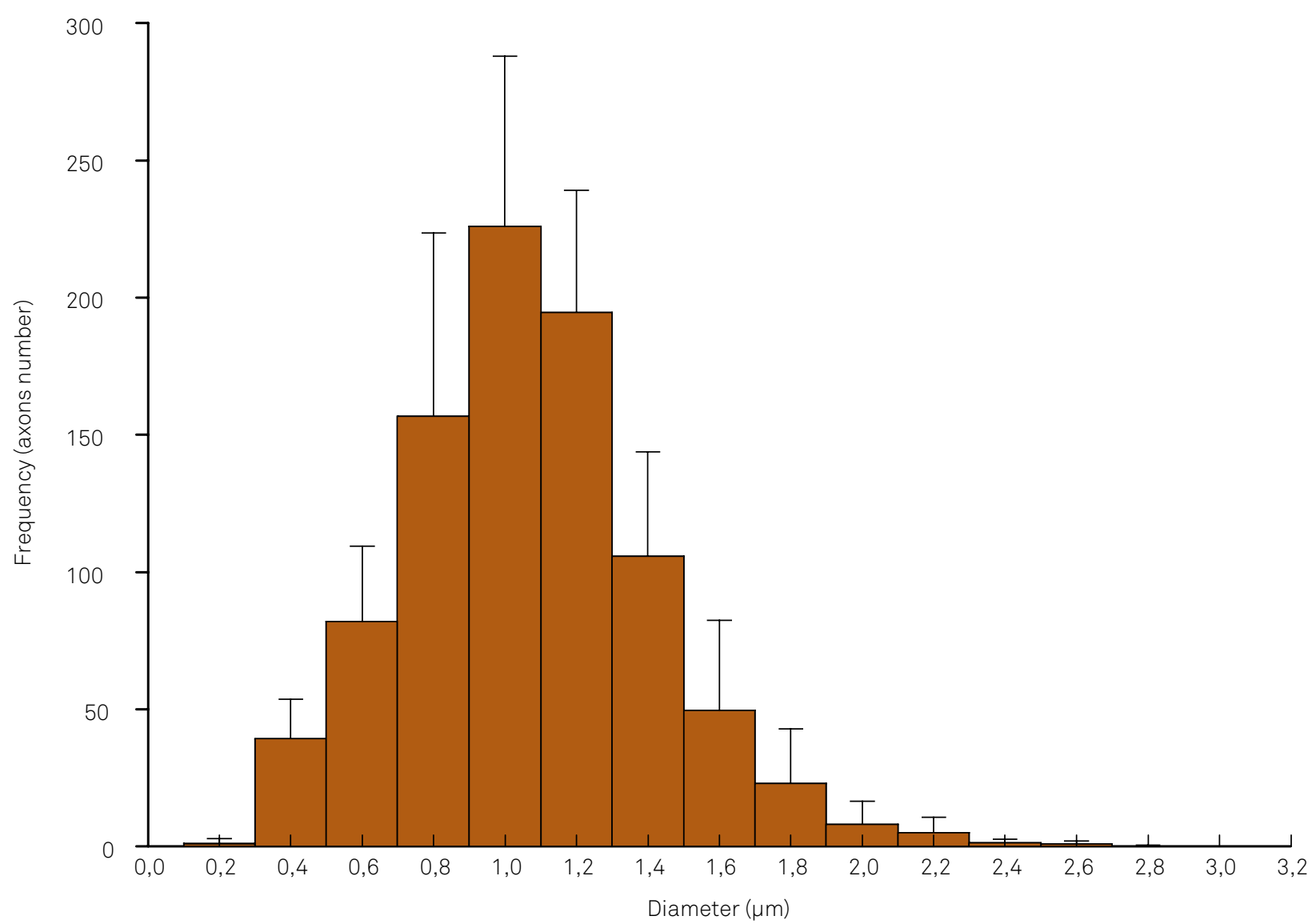

Figure 4. Transverse section through the distal level of a Wistar rat fibular nerve. Images of the following structures can be seen: unmyelinated fibers (UF) and axons (ax) of varied diameters, a Schwann cell nucleus (SCN), myelinated fibers (M), and collagen fibers (C). Yellow line surrounds an unmyelinated axon. Transmission electron microscopy - 14,000X. Bar $=2 \mu \mathrm{m}$. 


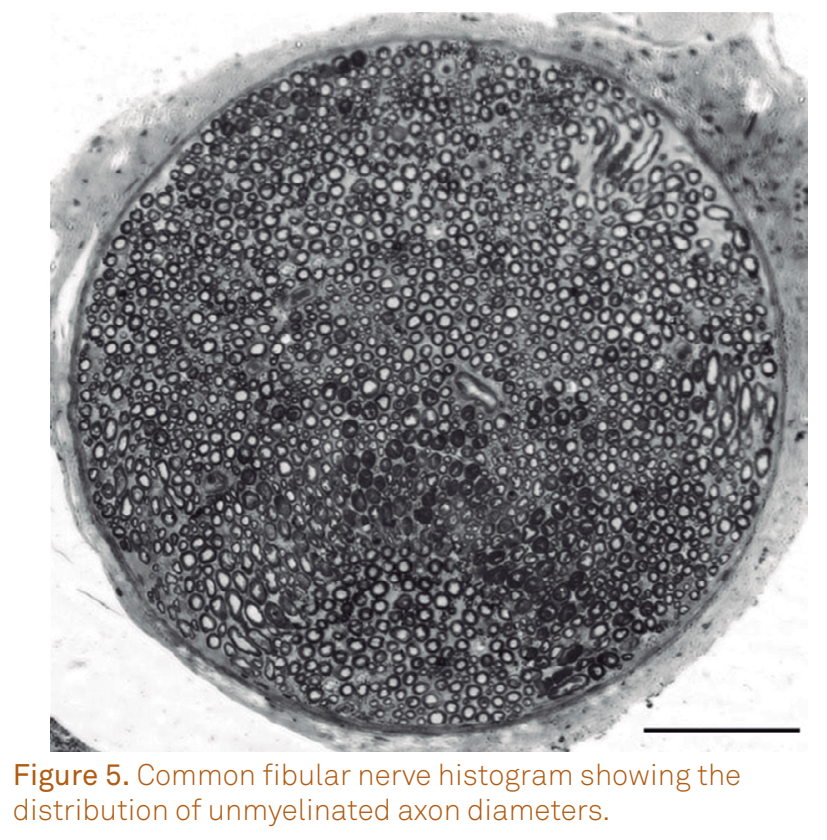

grids are associated with a higher chance of error, due to the overlapping of thin sections on the grid meshes divisions, hiding part of the images and limiting the evaluation. Oval grids do not obstruct any portion of the full fascicle image, allowing its entire area to be scanned. This may be one of the reasons why the other authors presented data that was based on scanning a smaller area of the nerve fascicle than we did. In a study, data were obtained from 3 to $70 \%$ of the cross-sectional area of the nerves examined and did not precisely indicate the fibular nerve area sampled ${ }^{14}$. Other investigation sampled 6 to $10 \%$ of the sectional nerve area ${ }^{15}$. The total number of unmyelinated axons was estimated based on the analysis of $15 \%$ of the nerve area in a third study ${ }^{16}$. Our quantification of the number of unmyelinated axons in the typical fibular nerve was based, on average, on measurements conducted over $60 \%$ of the nerve's cross-sectional area. The area sampled by the other authors was at least six times smaller. Their estimations were based on the proportion of both unmyelinated axons and myelinated fibers (the specific ratio was not given). We extrapolated the total number of axons from the scanned area to the complete fascicular area.

Another reason for differences between other authors' data and ours could be the age of the animals studied. We examined rats that were approximately 18 weeks old (130 days). Studies evaluated rats five and half weeks old (39 days) but without giving any age information ${ }^{14-16}$. The observed differences may be related to differences in the length of the developmental period. The growth process of the skeleton is completed between 120-140 days of age, and they are regarded as adults after that ${ }^{27}$. The process of growth and development in rats involves three distinct phases. The initial phase is termed hyperplasia ( first 17 days of life). The intermediate phase is referred to as hyperplasia-hypertrophy (17 to 48 days). The last

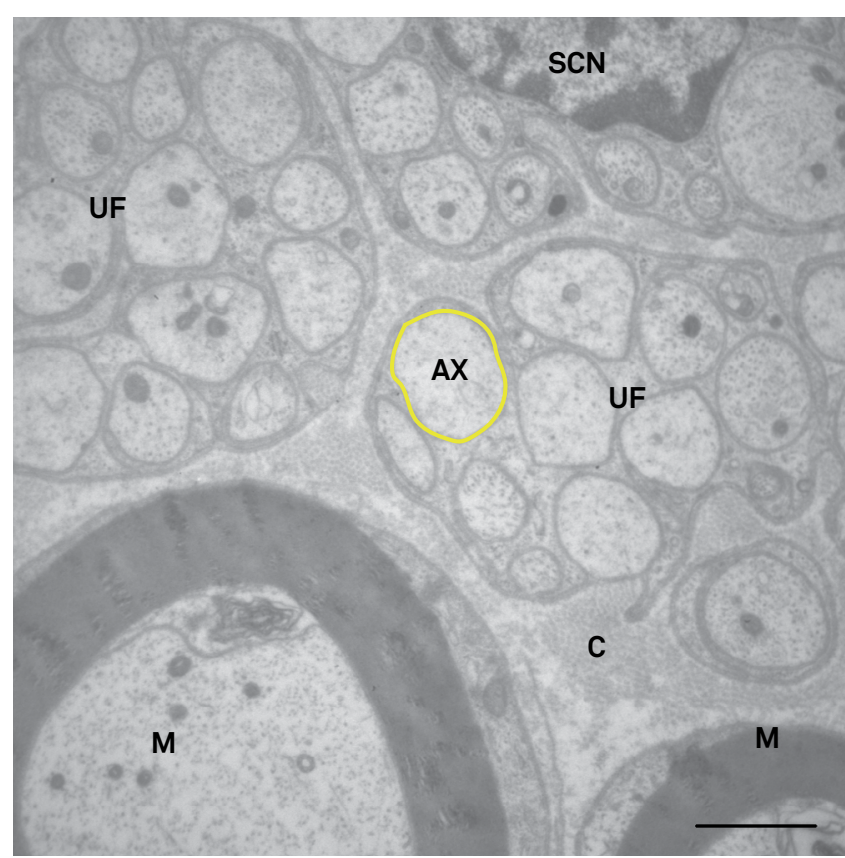

Figure 6. Transverse semithin section through the distal segment of the rat common fibular nerve. Toluidine blue. Bar $=100 \mu \mathrm{m}$.

phase called the storage period goes from 48 to 160 days of age $^{28}$. During the developmental period, the rat sciatic nerve is known to have more axons than are present in adult rats. Profuse axonal branching is eliminated during the process of maturation ${ }^{29}$. Comparative experimental studies may differ in their results due to the maturation of the rat's body and the accompanying morphological changes ${ }^{30}$. One author studied younger animals that were still growing, and we studied adult rats $^{14}$. The axonal diameters found in the same study were $0.78 \mu \mathrm{m}$ on average while ours were $0.96 \mu \mathrm{m}$. During the process of axonal maturation, the axonal diameter is less than in adult animals. Our sample size was larger than previous research groups. We evaluated ten animals while others studies included four, one, and six animals, respectively ${ }^{14,15,16}$. It is noteworthy that using Student's $t$ test, there are significant differences between our results and those of two others authors $(p=0.004 \text { and } p<0.001 \text { respectively })^{14,16}$.

The methodology that we have employed and the larger size of the nerve area sampled, both argue for the reliability of the findings presented here. Our findings indicate that the number of unmyelinated axons of the common fibular nerve is smaller and their axon diameters larger than have been recognized hitherto.

\section{Acknowledgments}

The authors thank Mr. Antonio Renato Meirelles e Silva, Mrs. Aracy Edwirges Vieira da Silva Dias, Mrs. Maria Teresa Picinoto Maglia and Mr. José Augusto Maulin for technical assistance, as well as Mr. Geraldo Cássio dos Reis for statistical analysis. 
1. Viterbo F, Trindade JC, Hoshino K, Mazzoni Neto A. Latero-terminal neurorrhaphy without removal of the epineural sheath. Experimental study in rats. Rev Paul Med.1992;110(6):267-75.

2. Viterbo F, Trindade JC, Hoshino K, Mazzoni Neto A. Two end-to-side neurorrhaphies and nerve graft with removal of the epineural sheath: experimental study in rats. Br J Plast Surg. 1994;47(2):75-80. doi:10.1016/0007-1226(94)90162-7

3. Viterbo F, Trindade JC, Hoshino K, Mazzoni Neto A. End-to-side neurorrhaphy with removal of the epineurial sheath: an experimental study in rats. Plast Reconstr Surg. 1994;94(7):1038-47. doi:10.1097/00006534-199412000-00019

4. Zhang Z, Soucacos PN, Beris AE, Bo J, loachim E, Johnson EO. Long-term evaluation of rat peripheral nerve repair with end-to-side neurorrhaphy. J Reconstr Microsurg. 2000;16(4):303-11. doi:10.1055/s-2000-7338

5. Zhang Z, Soucacos PN, Bo J, Beris AE, Malizos KN, loachim E et al. Reinnervation after end-to-side nerve coaptation in a rat model. Am J Orthop (Belle Mead NJ). 2001;30(5):400-6.

6. De Sá JM, Mazzer N, Barbieri CH, Barreira AA. The end-to-side peripheral nerve repair. Functional and morphometric study using the peroneal nerve of rats. J Neurosci Methods. 2004;136(1):45-53. doi:10.1016/j.jneumeth.2003.12.018

7. Brenner MJ, Dvali L, Hunter DA, Myckatyn TM, Mackinnon SE. Motor neuron regeneration through end-to-side repairs is a function of donor nerve axotomy. Plast Reconstr Surg. 2007;120(1):215-23. doi: 10.1097/01.prs.0000264094.06272.67

8. Silva DN, Silva AC, Aydos RD, Viterbo F, Pontes ER, Odashiro DN et al. Nerve growth factor with fibrin glue in end-to-side nerve repair in rats. Acta Cir Bras. 2012;27(4):325-32. doi:10.1590/S0102-86502012000400008

9. Maciel FO, Viterbo F, Chinaque LF, Souza BM. Effect of electrical stimulation of the cranial tibial muscle after end-to-side neurorrhaphy of the peroneal nerve in rats. Acta Cir Bras. 2013;28(1):39-47. doi:10.1590/S0102-86502013000100007

10. Yang LM, Wu YX, Zhang XP, Li XH. Experimental research on end-to-side anastomosis of peripheral nerves and effect of FK506 on end-to-side anastomosis. Bratisl Lek Listy. 2014;115:625-31.

11. Liu HF, Chen ZG, Fang TL, Arnold P, Lineaweaver WC, Zhang $J$. Changes of the donor nerve in end-to-side neurorrhaphies with epineurial window and partial neurectomy: a long-term evaluation in the rat model. Microsurgery. 2014;34(2):136-44. doi:10.1002/micr.22167

12. Liu HF, Chen ZG, Shen HM, Zhang H, Zhang J, Lineaweaver WC et al. Efficacy of the end-to-side neurorrhaphies with epineural window and partial donor neurectomy in peripheral nerve repair: an experimental study in rats. J Reconstr Microsurg. 2015;31(1):31-8. doi:10.1055/s-0034-1382263

13. Fagotti de Almeida CE, Farina Junior JA, Colli BO. Morphometric and functional analysis of axonal regeneration after end-to-end and end-to-side neurorrhaphy in rats. Plast Reconstr Surg Glob Open. 2015;3(3):e326. doi:10.1097/GOX.0000000000000280

14. Schmalbruch H. Fiber composition of the rat sciatic nerve. Anat Rec. 1986;215(1):71-81. doi:10.1002/ar.1092150111
15. Toft PB, Fugleholm K, Schmalbruch H. Axonal branching following crush lesions of peripheral nerves of rat. Muscle Nerve. 1988;11(8):880-9. doi:10.1002/mus.880110813

16. Wesselmann U, Kerns JM, Rymer WZ. Laser effects on myelinated and nonmyelinated fibers in the rat peroneal nerve: a quantitative ultrastructural analysis. Exp Neurol. 1994;129(2):257-65. doi:10.1006/exnr.1994.1168

17. Kovacic U, Tomsic M, Sketelj J, Bajrović FF. Collateral sprouting of sensory axons after end-to-side nerve coaptation: a longitudinal study in the rat. Exp Neurol. 2007;203(2):358-69. doi:10.1016/j.expneurol.2006.08.018

18. Kovacic U, Sketelj J, Bajrović FF. Sex-related differences in recovery of cutaneous nociception after end-to-side nerve repair in the rat. J Plast Reconstr Aesthet Surg. 2009;62(6):806-13. doi:10.1016/j.bjps.2007.09.046

19. Kovacic U, Sketelj J, Bajrović FF. Effect of aging on recovery of cutaneous nociception after end-to-side nerve repair in the rat. Ann Plast Surg. 2009;62(4):439-45. doi:10.1097/SAP.0b013e318180c8cb

20. Nascimento-Elias AH. Veículos, indutores e tubulização látero-terminal na regeneração do nervo periférico [thesis]. Ribeirão Preto: Universidade de São Paulo; 2013.

21. Santos AP, Suaid CA, Fazan VP, Barreira AA. Microscopic anatomy of brachial plexus branches in Wistar rats. Anat Rec (Hoboken). 2007;290(5):477-85. doi:10.1002/ar.20519

22. Morris JH, Hudson AR, Weddell G. A study of degeneration and regeneration in the divided rat sciatic nerve based on electron microscopy II. The development of the "regenerating unit”. Z Zellforsch Mikrosk Anat. 1972;124(1):103-30. doi:10.1007/BF00335457

23. Fazan VP, Salgado HC, Barreira AA. Aortic depressor nerve unmyelinated fibers in spontaneously hypertensive rats. Am J Physiol Heart Circ Physiol. 2001;280(4):H1560-4.

24. Fazan VP, MaX, Chapleau MW, Barreira AA. Qualitative and quantitative morphology of renal nerves in C57BL/6J mice. Anat Rec. 2002;268(4):399-404. doi:10.1002/ar.10174

25. Marques VD, Barreira AA, Davis MB, Abou-Sleiman PM, Silva WA $\mathrm{Jr}$, Zago MA et al. Expanding the phenotypes of the Pro56Ser VAPB mutation: proximal SMA with dysautonomia. Muscle Nerve. 2006;34(6):731-9. doi:10.1002/mus.20657

26. Oliveira AL, Fazan VP, Marques Junior W, Barreira AA. Dorsal cutaneous branch of the ulnar nerve: a light and electron microscopy histometric study. J Peripher Nerv Syst. 2011;16(2):98-101. doi:10.1111/j.1529-8027.2011.00326.x

27. Hughes PCR, Tanner JM. The assessment of skeletal maturity in the growing rat. J. Anat. 1970;106(2):371-402.

28. Enesco M, Leblond P. Increase in cell number as factor in the growth of the organs and tissues of the young male rat. J Embryol Exp Morphol. 1962;10:530-62.

29. Jeng CB, Chung K, Coggeshall RE. Postnatal loss of axons in normal rat sciatic nerve. J Comp Neurol. 1986;244(4):445-50. doi:10.1002/cne.902440404

30. Bolaños MAC, De Arruda M. Velocidade de crescimento a partir do peso corporal de ratos machos Wistar. Rev Bras Obes Nutr Emagrecimento. 2009;3(18):478-84. 


\section{Erratum}

Arquivos de Neuropsiquiatria. 2016;74(5):367-72. doi:10.1590/0004-282X20160051

The correct legends for the Figures 4, 5 and 6 are:

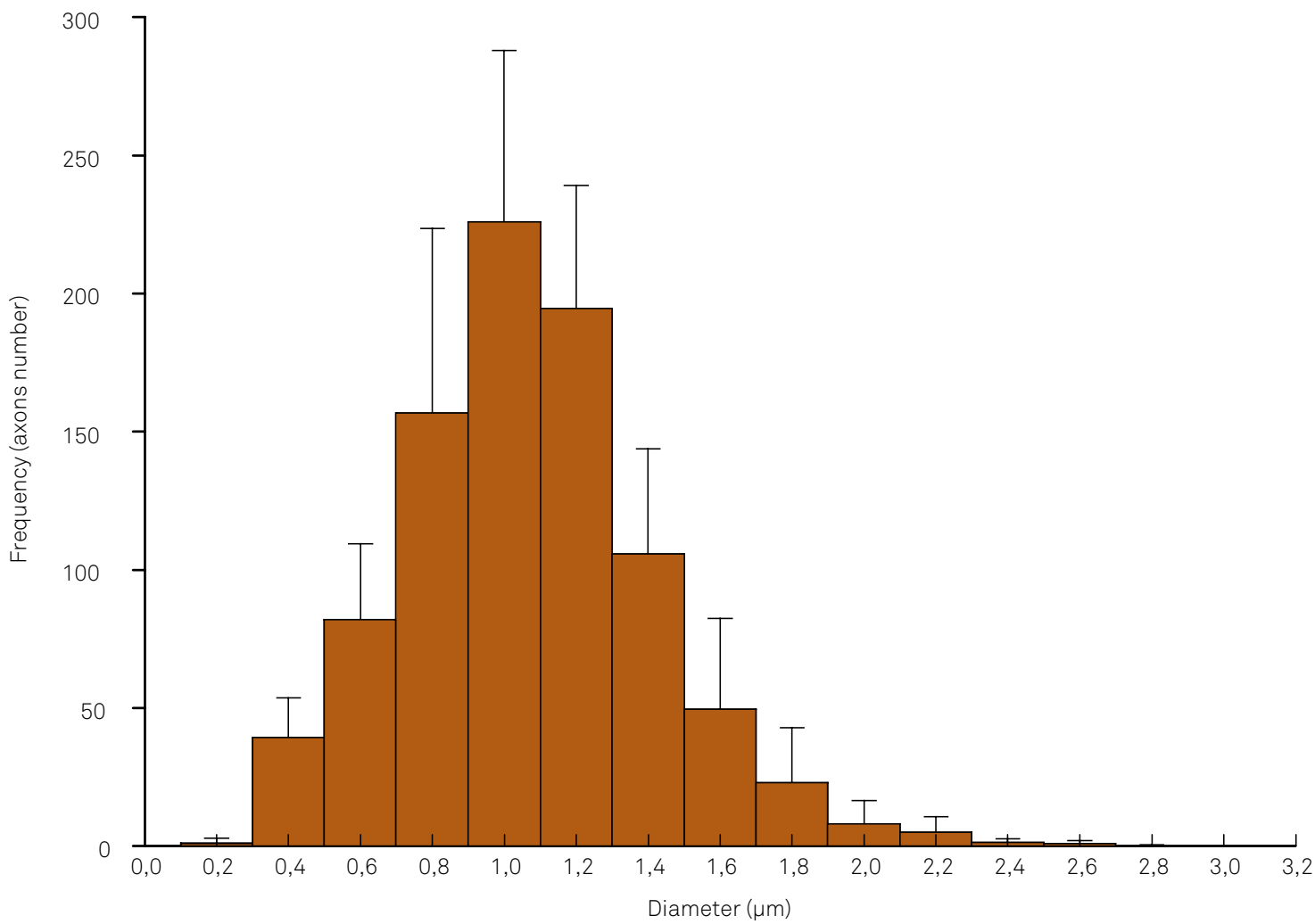

Figure 4. Common fibular nerve histogram showing the distribution of unmyelinated axon diameters.

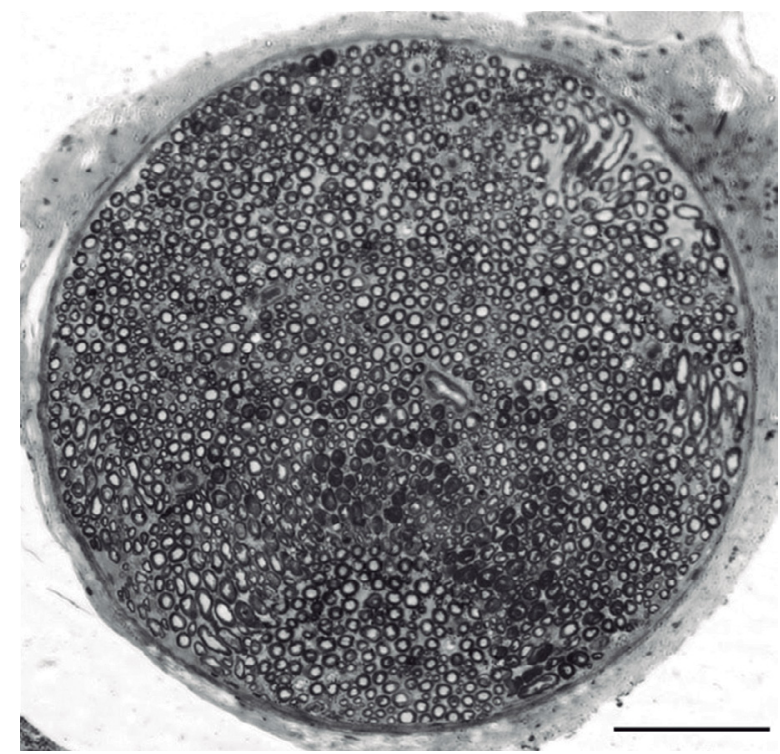

Figure 5. Transverse semithin section through the distal segment of the rat common fibular nerve. Toluidine blue. Bar $=100 \mu \mathrm{m}$.

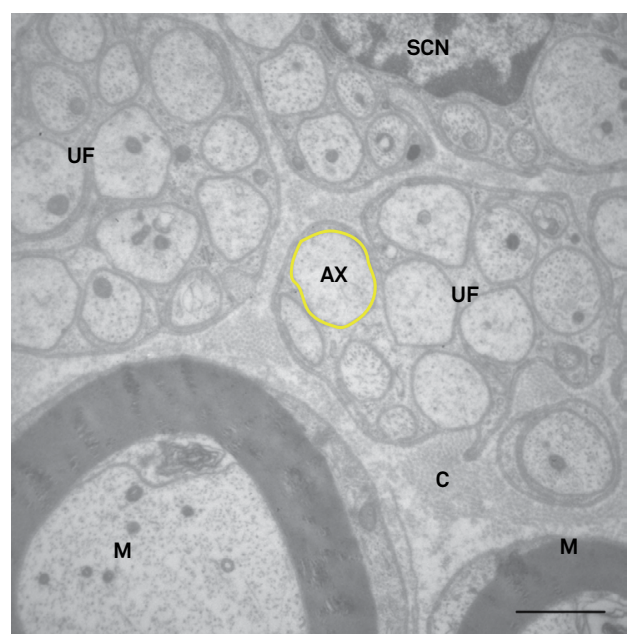

Figure 6. Transverse section through the distal level of a Wistar rat fibular nerve. Images of the following structures can be seen: unmyelinated fibers (UF) and axons (ax) of varied diameters, a Schwann cell nucleus (SCN), myelinated fibers (M), and collagen fibers (C). Yellow line surrounds an unmyelinated axon. Transmission electron microscopy $-14,000 \mathrm{X}$. Bar $=2 \mu \mathrm{m}$. 